\title{
Experimental infection of coho salmon Oncorhynchus kisutch by exposure of skin, gills and intestine with Piscirickettsia salmonis
}

\author{
P. A. Smith*, M. E. Rojas, A. Guajardo, J. Contreras, M. A. Morales, J. Larenas \\ Department of Animal Pathology, Unit of Pathology of Aquatic Animals, Faculty of Veterinary Sciences, University of Chile, \\ Santiago, Chile
}

\begin{abstract}
Piscirickettsiosis pathogenesis was examined using some tissues as entry portals of Piscirickettsia salmonis in coho salmon. Juvenile fish, weighing approximately $8.4 \mathrm{~g}$, were used in this trial. Inocula were prepared using the strain SLGO-95 of P. salmonis. The micro-organism was cultured in the CHSE-214 cell line as described by Fryer et al. (1990) and doses containing $10^{4.7}$ and $10^{3.7}$ TCID $_{50}$ were prepared. Each dose was used to infect the fish via skin, gills and intestine. Skin and gills were exposed by calibrated drops, and the intestine by an intubation through the anal opening. Some fish were injected intraperitoneally with the same $P$. salmonis doses, as positive virulence controls. Sham-inoculated fish for each of the tested routes were also included as negative controls. Piscirickettsiosis was experimentally reproduced with all the inoculation methods. Cumulative mortalities and survival analyses showed that the most effective entry portal was skin followed by intestinal intubation and finally by gill infection.
\end{abstract}

KEY WORDS: Piscirickettsia salmonis $\cdot$ Pathogenesis $\cdot$ Fish disease $\cdot$ Coho salmon

\section{INTRODUCTION}

Piscirickettsiosis, the disease caused by Piscirickettsia salmonis (Fryer et al. 1992), has been the most important sanitary constraint of the Chilean salmonid aquaculture since 1989 (Fryer et al. 1990, Cvitanich et al. 1991). Coho salmon Oncorhynchus kisutch is described as the most susceptible salmonid fish to piscirickettsiosis (Garcés et al. 1991, Smith et al. 1996a). In 2002, P. salmonis was diagnosed as the aetiological agent of approximately $80 \%$ of the moribund field coho salmon in Chile (Anonymous 2002).

The economical impact of piscirickettsiosis in salmon aquaculture indicates that further scientific research is still required to develop efficient control measures against this disease and understanding its pathogenesis may lead to reach this goal. In the present work the entry portal of $P$. salmonis was investigated by use of selected experimental infections in juvenile coho salmon.

\section{MATERIALS AND METHODS}

Fish. 650 coho salmon weighing approximately $8.4 \mathrm{~g}$ $(\mathrm{SD}=1.1)$ at inoculation time were used. The infectivity trial was performed in an experimental facility using an inflow of filtrated and dechlorinated drinkable water (Aguasín model CA-30). The effluent was irradiated with ultraviolet light and treated with 5 ppm sodium hypochlorite. Initially, fish were held in a $2.5 \mathrm{~m}^{3}$ circular plastic tank, supplied with flow-through water $\left(61 \mathrm{~min}^{-1}\right)$ at $13.2^{\circ} \mathrm{C}(\mathrm{SD}=0.3)$ and permanent aeration, for $45 \mathrm{~d}$ prior to bacterial exposure. During this period, 50 randomly selected fish were examined for virology, bacteriology and parasitology by standard methodology (Thoesen 1994). Kidney smears of these fish were analyzed by indirect immunofluorescent test (IFAT), following the method described by Lannan et al. (1991), to confirm the absence of Piscirickettsia salmonis. After being inoculated the other 600 experimental fish were allotted to 2 cylindrical 5001 fibre- 
glass tanks, with 300 individuals each, to have a replication of the experimental groups. These tanks were supplied with flow-through water $\left(31 \mathrm{~min}^{-1}\right)$ with permanent aeration. Water temperature was $13.8^{\circ} \mathrm{C}(\mathrm{SD}=$ 0.6). Fish were marked by an appropriate combination of small clippings to recognize the group to which they belonged. They were fed once a day at $1 \%$ of body weight rate on dry commercial pellets.

Bacterium. Strain SLGO-95 of Piscirickettsia salmonis (Smith et al. 1996b) was grown in monolayers of the CHSE-214 cell line (Lannan et al. 1984). Cells were cultured with Minimal Essential Medium (MEM) with Earle's salts and supplemented with $10 \%$ fetal calf serum (MEM-10). The culture media did not have antimicrobials as described by Garcés et al. (1991). Cultures were incubated at $17^{\circ} \mathrm{C}$ and harvested when the cytopathic effect was complete. This infectious supernatant was centrifuged at $2000 \times g$ for $30 \mathrm{~min}$ at $15^{\circ} \mathrm{C}$ and the pellet resuspended with enough MEM to get $1 / 10$ of the original volume. This $10 \times$ concentrated suspension was titrated by endpoint dilution assay $\left(\mathrm{TCID}_{50} \mathrm{ml}^{-1}\right.$ ) in 96-well plates seeded with CHSE-214 cells with 6 wells per dilution. Dilution endpoints were calculated using the method of Reed \& Müench (1938).

Infectivity study. Fish $(\mathrm{n}=400)$ were exposed to the bacterium using 4 entry sites which were skin (SE), gills (GE) intestine (IE) and peritoneum by intraperitoneal injection (IP). The IP method was used as a control of the bacterial virulence. Two doses of Piscirickettsia salmonis were applied to each site of entry $\left(10^{4.7}\right.$ and $10^{3.7} \mathrm{TCID}_{50}$ ) with 50 fish per dose. In addition, 200 fish were sham-inoculated with MEM as negative controls: 50 with IP, 50 with IE, 50 with SE and 50 with GE. In total, 12 groups of fish were used in the infectivity trial and each of them consisted of 25 individuals with their respective replicates. Before inoculation, fish were fasted for $48 \mathrm{~h}$ and sedated with tricaine methyl sulfonate (MS-222, Sigma). After inoculation, each group was held in an individual bath containing $7 \mathrm{l}$ of $\mathrm{MEM}$ at $17^{\circ} \mathrm{C}$ for $30 \mathrm{~min}$ under permanent aeration, and afterward returned to the 5001 tanks. In the case of the $\mathrm{SE}$ and GE, this bathing procedure was used to avoid the immediate contact of the bacteria with fresh water, which is a hostile environment to this bacterium (Lannan \& Fryer 1994), and for the other inoculation methods (IP and IE) it was used only to have equivalent stress conditions among the experimental treatments. Dead fish were examined by necropsy, routine parasitological and microbiological methods and IFAT to detect $P$. salmonis from kidney smears to determine the cause of the death. The same examination was performed on 20 sham-inoculated fish, 5 per group, at the end of the experiment. Fish were observed until Day 35 postinoculation (p.i.). The volume of the inocula was adjusted to be suitable to each infection method as described below:

IP: Fish were injected with $100 \mu \mathrm{l}$. IE: $30 \mu \mathrm{l}$ were placed inside the descending intestine, by intubation through the anal opening, $9 \mathrm{~mm}$ from the anus by means of a polytetrafluoroethylene (Teflon) cylindrical flexible probe $(24 \mathrm{G}$, internal diameter $0.5 \mathrm{~mm}$, Nipro Medical Industries) connected to a tuberculin syringe. SE: $5 \mu \mathrm{l}$ were deposited on the skin of the left side of the fish and gently spread all over a region extending from $5 \mathrm{~mm}$ behind the operculum to the adipose fin as a posterior limit. The spreading of the drop was performed by 3 back and forth movements tangentially to the fish surface so as to obtain a film using the same kind of flexible Teflon tubes used in the intestinal intubation, while taking care not to remove the skin mucus. GE: $5 \mu$ l were dropped on the external surface of the first branchial arch of the left side of the fish.

\section{RESULTS}

Piscirickettsiosis was experimentally reproduced, although with different mortality rates, with the 4 inoculation methods (Figs. 1 \& 2). Diseased fish exhibited clinical signs and gross pathological lesions consistent with those described in coho salmon with piscirickettsiosis (Fryer et al. 1990, Cvitanich et al. 1991). In addition, fish infected by SE showed lesions in the area

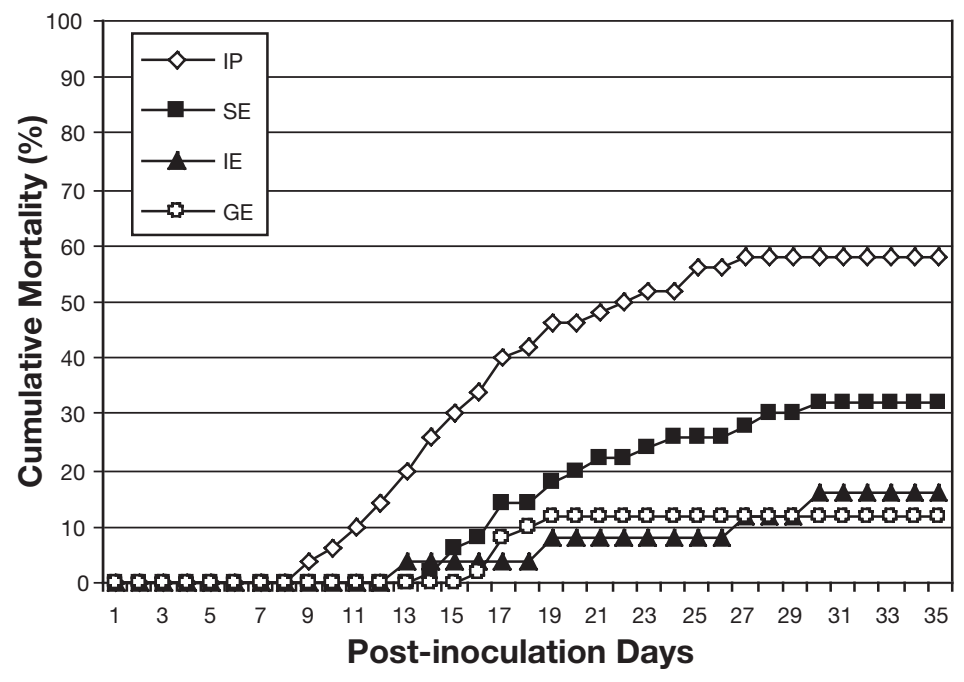

Fig. 1. Oncorhynchus kisutch. Cumulative mortality (\%) of coho salmon exposed via skin (SE), gills (GE), intestine (IE) and intraperitoneal (IP) to $10^{3.7} \mathrm{TCID}_{50}$ fish $^{-1}$ of Piscirickettsia salmonis 


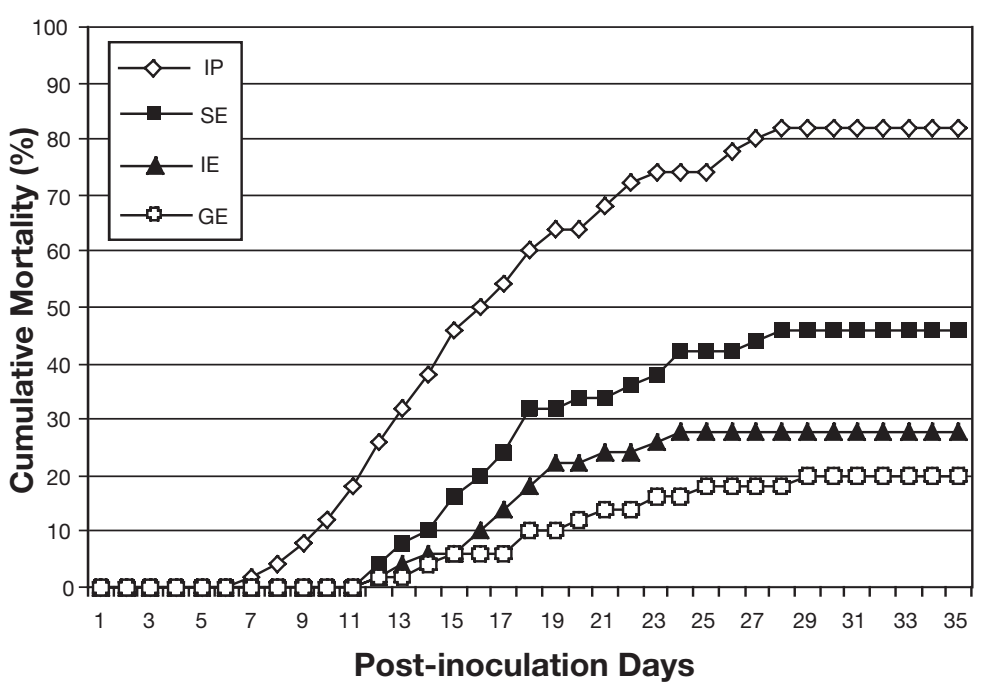

Fig. 2. Oncorhynchus kisutch. Cumulative mortality (\%) of coho salmon exposed via skin (SE), gills (GE), intestine (IE) and intraperitoneal (IP) to $10^{4.7} \mathrm{TCID}_{50}$ fish $^{-1}$ of Piscirickettsia salmonis

of the skin exposed to the bacteria that started with scale loss followed by the exhibition of small whitish indurated nodules and ulcerations of about $1 \mathrm{~mm}$ in diameter.

Piscirickettsia salmonis was detected in all, except one, dead fish by IFAT kidney smears. The negative salmon, which had been IP inoculated $\left(10^{4.7} \mathrm{TCID}_{50}\right)$, was autolytic and the cause of death could not be determined. Necropsy, parasitological and microbiological examination of mortalities showed no other pathogens. No clinical signs of disease or mortalities were shown by the sham-inoculated fish and the individuals tested at the end of the trial were negative by IFAT to $P$. salmonis.

Cumulative mortalities of fish infected with $10^{4.7}$ and $10^{3.7}$ TCID $_{50}$ were 82 and $58 \%$ with IP injection, 46 and $32 \%$ with SE, 28 and $16 \%$ with IE and 20 and $12 \%$ with GE, respectively (Figs. 1 \& 2), suggesting a doseresponse effect to each route of entry. Survival data were obtained with the non-parametric method of Kaplan \& Meier and compared with the Wilcoxon test (Lee \& Wang 2003). With the 2 doses of Piscirickettsia salmonis used, the lowest survivability of fish was obtained with IP followed by SE, IE and GE, respectively. In comparing survivability values among these inoculation procedures, all of them, except those between IG and GE, showed significant differences ( $p \leq 0.05)$.

\section{DISCUSSION}

The infectivity experiments showed that Piscirickettsia salmonis can enter coho salmon through skin, intestine and gills, and piscirickettsiosis could be reproduced in these fish. Among the routes tested, skin proved to be the most efficient entry site of this bacterium, followed by intestine and then gills. In a similar study with rainbow trout Oncorhynchus mykiss, skin was also the most effective portal of entry of P. salmonis (Smith et al. 1999) although trout infected by GE exhibited the same cumulative mortalities (24\%) as those exposed to the bacteria by IE. In contrast, the higher rate of mortality following IE compared with GE in this study might be explained by the difference in the salmonid species used (coho salmon vs rainbow trout). A more probable cause could also be that in this work all the fish were held in a bath with MEM for $30 \mathrm{~min}$ after their inoculation with $P$. salmonis so the different fish groups experienced the same stressing conditions, whereas in the research with the rainbow trout only the fish infected by SE and GE were subsequently bathed with MEM and not the ones inoculated by IE. The mortality relationship between IE and GE obtained in this study with coho salmon is potentially more accurate than that with rainbow trout where the efficiency of the IE route could have been underestimated in comparative terms. In Atlantic salmon Salmo salar evidence has been provided that fish inoculated with $P$. salmonis by instillation of the gills had significant higher probability of dying than fish infected by the oral route (Almendras et al. 1997), but intestinal and skin exposure were not addressed in this work.

The high cumulative mortalities obtained after SE strongly suggest that skin is a major entry route of Piscirickettsia salmonis to coho salmon. Nevertheless, in spite of the care used to spread the inocula in the SE method, some unnoticed mucus removal might have occurred that probably facilitated the establishment of the initial bacterial infection of the skin. Removal of mucus and/or cuticular secretion of skin has been reported to significantly increase the efficiency of adherence and invasion of a number of bacterial pathogens in teleost fish (Crouse-Eisnor et al. 1985, Svendsen \& Bogwald 1997, Madetoja et al. 2000). The first hindrance for a pathogenic bacteria interacting with a fish host is the mucus which contains specific and non-specific components of the immune system (Shephard 1994).

It is interesting that Piscirickettsia salmonis can easily gain access to the fish and reproduce the disease in a more efficient way through the skin than through the gills. This is in spite of the fact that the branchial surface is largely covered by a simple epithelium and theoretically should be easier to penetrate than the 
skin which is, histologically, a thicker and a more compact natural obstacle (Evelyn 1996). Consistent with this hypothesis, undamaged gills have been reported to be the entry site for a number of viral and bacterial fish pathogens (Evelyn 1996), including the spring viremia carp virus (Ahne 1978), infectious haematopoietic necrosis virus (Mulcahy et al. 1983), Vibrio anguillarum (Nelson et al. 1985, Baudin-Laurencin \& Germon 1987), Aeromonas salmonicida (Tatner et al. 1984) and Pasteurella piscicida (Kawahara et al. 1989). Reports of microbial invasion of fish via intact skin are scarce, the first evidence of this being provided by $V$. anguillarum in experimental infections of ayu Plecoglossus altivelis, in which a patch of paper soaked in the bacterial suspension was used as the inoculation method (Kanno et al. 1989). In salmonid fish, besides data on P. salmonis (Smith et al. 1999), the results reported by Effendi \& Austin (1995) also suggests that undamaged skin may be one of the entry sites of $A$. salmonicida, but in this case a swabbing method of inoculation was used which could have facilitated bacterial entry. Although it has been suggested that the gills are the primary site of antigen uptake in bath immunization of fish, it was demonstrated that the principal site of uptake in rainbow trout using soluble (Ototake et al. 1996) and particulate (Moore et al. 1998) antigens is the skin with a lesser role for the gills.

Bacterial invasion through intact skin in fish, such as that showed by Piscirickettsia salmonis, may be facilitated by an eventual interaction with the Malpighian cells that are located in the surface of the skin of teleosts (Whitear 1970).

Despite the absence of wounds in the skin of the experimental fish, Piscirickettsia salmonis may have initiated their infection process by attaching to the surfaces of microscopic injuries which are frequently found in cultured salmon (Turnbull et al. 1996). Kiryu \& Wakabayashi (1999) reported that in intact rainbow trout, latex microspheres only adhered to the surface of natural microscopic injuries of these fish and not to healthy sites of the skin properly covered by the cuticular secretion.

Interpretation of the mortalities obtained after IE is difficult because the intubation technique for bacterial exposure is an artificial procedure. Theoretically these results suggest that ascending colonization of the intestine through the anal opening and/or degluted food contaminated with viable Piscirickettsia salmonis might lead to infection of the fish through the gut epithelium in natural conditions. Nevertheless, these hypothetical conditions are not likely to occur because ascending infections would move against the natural flow of the intestinal contents; on the other hand, oral infections with $P$. salmonis are effectively inactivated by the stomach environment as was documented in rainbow trout inoculated by intragastric intubation (Smith et al. 1999).

Gills were also shown to be also an entry site to Piscirickettsia salmonis in coho salmon, which agrees with the results reported for rainbow trout (Smith et al. 1999) and Atlantic salmon (Almendras et al. 1997).

Results showed that Piscirickettsia salmonis can penetrate, and then systemically invade coho salmon, through skin and mucous membranes, both of which appear intact at a macroscopical level, and that the skin is probably the most important site of entry of this bacterium in salmonid fish.

Acknowledgements. We thank Dr. D. Elliot for her enlightening comments and generous help. We are also grateful to Prof. A. M. Espinoza and Dr. V. Rojas for their technical help. This work was supported by grant 1010544 of the Chilean Fund For Science and Technology (FONDECYT)

\section{LITERATURE CITED}

Ahne W (1978) Uptake and multiplication of spring viremia of carp virus in carp, Cyprinus carpio L. J Fish Dis 1: 265-268

Almendras F E, Fuentealba IC, Jones SRM, Markham F, Spangler E (1997) Experimental infection and horizontal transmission of Piscirickettsia salmonis in freshwaterraised Atlantic salmon, Salmo salar L. J Fish Dis 20: $409-418$

Anonymous (2002) Parámetros productivos. Columna de Aquatic Health Chile Ltda. Aquanoticias 73:74-75

Baudin-Laurencin F, Germon E (1987) Experimental infection of rainbow trout, Salmo gairdneri R, by dipping in suspensions of Vibrio anguillarum: Ways of penetration; influence of temperature and salinity. Aquaculture 67: 203-205

Crouse-Eisnor RA, Cone DK, Odense PH (1985) Studies on relations of bacteria with skin surface of Carassius auratus L. and Poecilia reticulata. J Fish Biol 27:395-402

Cvitanich JD, Gárate O, Smith CE (1991) The isolation of a rickettsia-like organism causing disease and mortality in Chilean salmonids and its confirmation by Koch's postulate. J Fish Dis 14:121-145

Effendi I, Austin B (1995) Uptake of Aeromonas salmonicida by Atlantic salmon (Salmo salar L.). Bull Eur Assoc Fish Pathol 15:115-118

Evelyn TPT (1996) Infection and disease. In: Iwawa G, Nakanisi $T$ (eds) The fish immune system. Organism, pathogen, and environment. Academic Press. Hoar WS, Randall DJ, Farrel AP (series eds) Vol 15 Fish Physiology Series, San Diego, p 339-366

Fryer JL, Lannan CN, Garcés LH, Larenas JJ, Smith PA (1990) Isolation of a rickettsiales-like organism from diseased coho salmon (Oncorhynchus kisutch) in Chile. Fish Pathol 25:107-114

Fryer JL, Lannan CN, Giovanonni SJ, Wood ND (1992) Piscirickettsia salmonis gen. nov., sp. nov., the causative agent of an epizootic disease in salmonid fishes. Int J Syst Bacteriol 42:120-126

Garcés LH, Larenas JJ, Smith PA, Sandino S, Lannan CN, Fryer JL (1991) Infectivity of a rickettsia isolated from coho salmon (Oncorhynchus kisutch). Dis Aquat Org 11:93-97

Kanno T, Nakai T, Muroga K (1989) Mode of transmission of 
vibriosis among ayu Plecoglossus altivelis. J Aquat Anim Health 1:2-6

Kawahara E, Kawai K, Kusuda R (1989) Invasion of Pasteurella piscicida in tissues of experimentally infected yellow tail Seriola quinqueradiata. Nippon Suisan Gakkaishi 55:499-501

Kiryu I, Wakabayashi H (1999) Adherence of suspended particles to the body of surface of rainbow trout. Fish Pathol 34:177-182

Lannan CN, Fryer JL (1994) Extracellular survival of Piscirickettsia salmonis. J Fish Dis 17:545-548

Lannan CN, Winton JR, Fryer JL (1984) Fish cell lines: establishment and characterization of 9 cell lines from salmonids. In Vitro 20:671-676

Lannan CN, Ewing SA, Fryer JL (1991) A fluorescent antibody test for detection of the rickettsia causing disease in Chilean salmonids. J Aquat Anim Health 3:229-234

Lee ET, Wang JW (2003) Statistical methods for survival data analysis, 3rd edn. John Wiley \& Sons, Hoboken, NJ

Madetoja J, Nyman P, Wiklund T (2000) Flavobacterium psychrophilum, invasion into and shedding by rainbow trout Oncorhynchus mykiss. Dis Aquat Org 43:27-38

Moore JD, Ototake M, Nakanishi T (1998) Particulate antigen uptake during immersion immunisation of fish: the effectiveness of prolonged exposure and the roles of skin and gill. Fish Shellfish Immunol 8:393-407

Mulcachy D, Pascho R, Jenes CK (1983) Detection of infectious haematopoietic necrosis virus in river water and demonstration of waterborne transmission. J Fish Dis 6: 321-330

Nelson JS, Rohovec JS, Fryer JL (1985) Location of Vibrio anguillarum in tissues of infected rainbow trout (Salmo gairdneri) using the flourescent antibody technique. Fish Pathol 20:229-235

Ototake M, Iwama GK, Nakanishi T (1996) The uptake of bovine serum albumin by the skin of bath-immunised rainbow trout Oncorhynchus mykiss. Fish Shellfish

Editorial responsibility: David Bruno,

Scotland, UK
Immunol 6:321-333

Reed LJ, Müench H (1938) A simple method of estimating fifty percent endpoints. Am J Hyg 27:493-497

Shephard KL (1994) Function of fish mucus. Rev Fish Biol Fish 4:401-429

Smith PA, Contreras JR, Garcés LH, Larenas JJ, CaswellReno P, Fryer JL (1996a) Experimental challenge of coho salmon (Oncorhynchus kisutch) and rainbow trout (Oncorhynchus mykiss) with Piscirickettsia salmonis. J Aquat Anim Health 8:130-134

Smith PA, Vecchiola IM, Oyanedel S, Garcés LH, Larenas J, Contreras J (1996b) Antimicrobial sensitivity of 4 isolates of Piscirickettsia salmonis. Bull Eur Assoc Fish Pathol 16: 164-168

Smith PA, Pizarro P, Ojeda P, Contreras J, Oyanedel S, Larenas J (1999) Routes of entry of Piscirickettsia salmonis in rainbow trout Oncorhynchus mykiss. Dis Aquat Org 37: 165-172

Svendsen YS, Bogwald J (1997) Influence of artificial wound and non-intact mucus layer on mortality of Atlantic salmon (Salmo salar L.) following a bath challenge with Vibrio anguillarum and Aeromonas salmonicida. Fish Shellfish Immunol 7:317-325

Tatner MF, Johnson CM, Horne MT (1984) The tissue localization of Aeromonas salmonicida in rainbow trout, Salmo gairdneri Richardson, following 3 methods of administration. J Fish Biol 25:95-108

Thoesen JC (ed) (1994) Suggested procedures for the detection and identification of certain fish and shellfish pathogens, 4th edn. Fish Health Section/American Fisheries Society, Bethesda, MD

Turnbull JF, Richards RH, Robertson DA (1996) Gross, histological and scanning electron microscopic appearance of dorsal fin rot in farmed Atlantic salmon, Salmo salar L., parr. J Fish Dis 19:415-427

Whitear M (1970) The skin surface of bony fishes. J Zool (Lond) 160:437-454

Submitted: February 7, 2003; Accepted: May 6, 2004

Proofs received from author(s): September 1, 2004 